\title{
Optimization of Bank Expenses on Marketing Communications
}

\author{
Abdul Rahman Barhaq \\ Deputy Chief Financial Officer, Da Afghanistan Bank (Central Bank of Afghanistan), Afghanistan \\ Oleg Radchenko \\ $\mathrm{PhD}$, the Head of the branch in Sumy regional administration Oschadbank, Ukraine.
}

\begin{abstract}
Dynamic changes in the banking services market that have taken place over the last decade, in particular, increased competition, expansion of banks with foreign capital, restructuring of the branch network of banks, situations of the market by the same type of services, etc., an increase in the level of supply in this market, which encourages banks to intensify efforts to strengthening its competitive position, attract new and maintain existing customers. At the same time as the supply on the market of banking services increased, demand for them decrease as a result of the general instability in the economy as a whole and in the labor market, in particular, a decrease in the profitability of the enterprises of the real sector of the economy, the solvency of the population and customer confidence in banks due to the global financial crisis. Under these conditions, most banks focus their efforts on finding effective tools for promoting their services, promoting sales, improving their image, conducting promotions and establishing public relations (PR), etc., which necessitates the development and application of a set of measures to manage the marketing communications of the bank.
\end{abstract}

Key words: bank expenses, mass marketing communications, scientific and methodical principles. JEL Classification: G21, G39.

(C) The Authors, 2018. This article is published with open access at Sumy State University.

\section{Introduction}

In a context of tight financial resources, banks are forced to reduce the amount of marketing communications spending. Effectiveness of the established budget of marketing communications is an urgent issue that faced the bank's management in times of crisis and exit from it. The presence of a significant number of marketing communications tools puts market makers ahead of a challenging choice. The formation of a balanced budget (both financial resources and tools) is definitely a topical issue that will be addressed by this unit.

Advertising, as the main and most popular among domestic banks, an instrument for promotion and promotion of goods in the banking market is a multifaceted phenomenon. The presence of a large number of tools or channels for the implementation of an advertising campaign causes a significant degree of uncertainty and complexity during the formation of the budget and the correct allocation of funds among all the selected tools, which is the main reasons for the implementation of budget optimization. Thus, the essence of optimizing the budget is to choose from the whole set of alternative tools namely those that during the given period will ensure the most effective and complete achievement of the goals and objectives set in the strategic plan of marketing communications.

\section{Literature review}

The analysis of scientific literature gives grounds to assert that there is no single point of view on this concept. Thus, the most frequently encountered are the following phrases: "marketing communications", "a complex of marketing communications", "communication policy". The analysis of the existing definitions of this concept gives grounds to distinguish four approaches to understanding the essence of marketing communications:

Marketing communications as a link between market actors (communication as a connection). This approach specifies marketing communications in the context of close relationships between contact audiences through advertising, PR, sales promotion, propaganda, personal sales, etc.

Marketing communications as a process of information exchange between market actors (process approach). It should be noted the close connection and similarity of this approach with the previous, but within the process approach there is a neglect of the process of establishing connections and focus only on the process of transmission and receipt of information.

Marketing communications as a set of elements transmitted between actors (structural approach). Understanding the essence of marketing communications within the framework of this approach is limited to the characterization 
of marketing communications as a set of signals addressed to consumers to focus their attention on the product or subject of management as a whole.

Marketing communications as a complex of measures of influence on consumers (integrated approach). This approach is based on determining the main measures applied by the entity to promote goods or services and to generate profits.

Thus, based on the analysis of approaches to the definition of the essence of marketing communications and its components, it is often understood in the literature in two aspects - broad and narrow (Figure 2). In broad terms, the Bank's marketing communications are a system of relationships between a bank and a client, taking into account the activity of a competitor, aimed at establishing bank links with consumers (customers) for further cooperation and obtaining economic and social benefits for all parties. In the narrow sense, it is a structured and coordinated set of measures for the formation and support of a stable and loyal customer base of the bank and promotion of sales, which is realized within the framework of the optimal budget formed through communication channels, through a mutually agreed system of marketing communications tools of the bank.

channels, through a mutually agreed system of marketing communications tools of the bank.

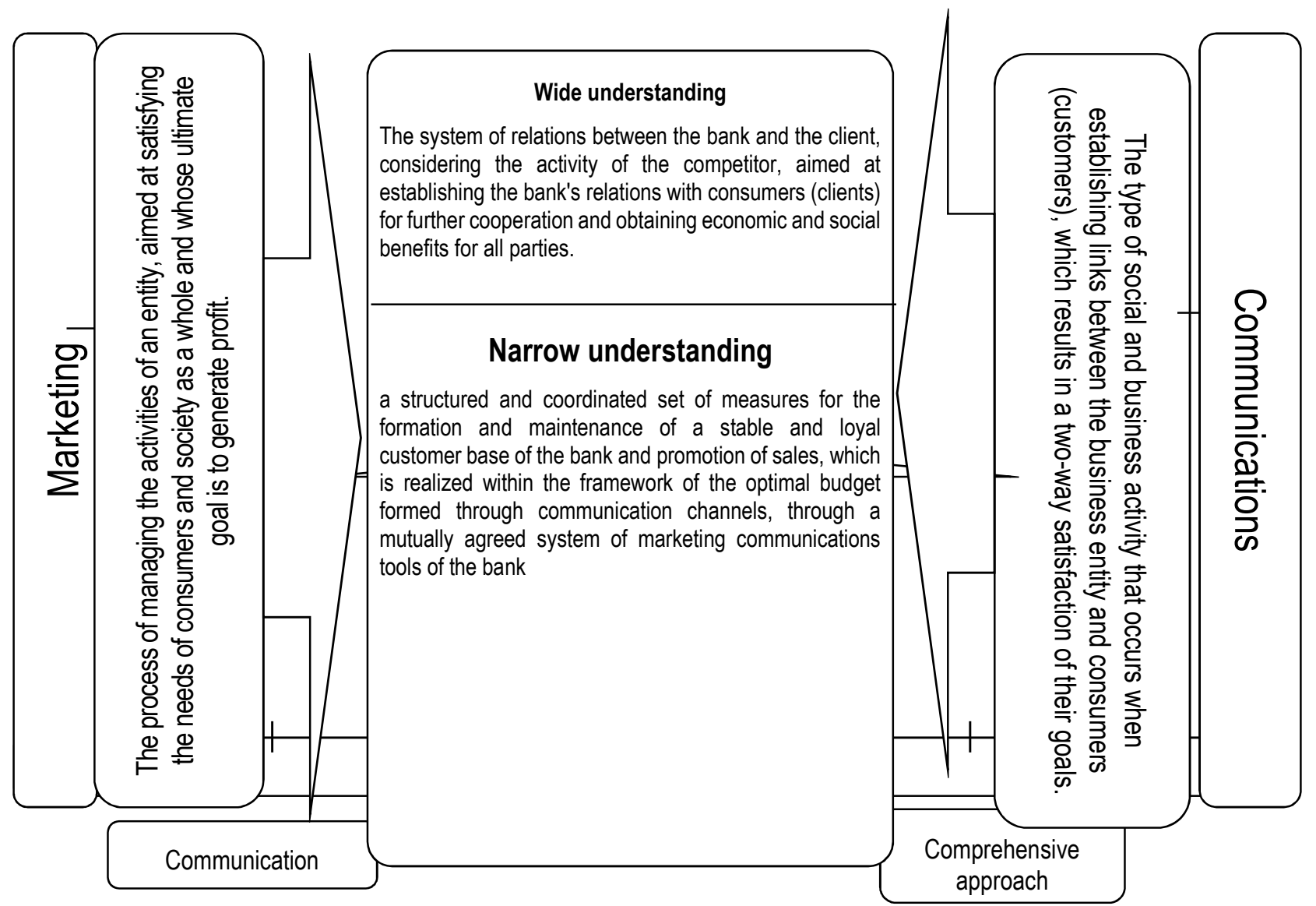

Figure 2. Generalization of the most established approaches to the essence of the marketing communications of the bank

In contrast to the established approaches, the concept of "marketing communications of the bank" is proposed to understand the totality of subject-object interconnections in the system "bank - potential consumer / client" that arise in the process of forming the need for banking service, development and implementation the mechanism of its satisfaction, informing of the competitive differences offered by the bank services, the emergence of feedback from customers on communication measures.

Unlike the existing ones, the author's approach implies:

1) interpretation of marketing communications of the bank not as separate measures, but more widely - as a set of subject-object interconnections;

2) expansion of the subject base of the formation of investigated relations by taking into account not only existing customers of the bank, but also potential consumers; 
3) taking into account the full cycle of object-object interaction by taking into account not only those relations that arise during the promotion of banking services in the market, but also those that are formed even at the stage of appearance in the consumer of a conscious need in it and the development of its mechanism pleasure;

4) bilateral exchange of information by taking into account not only the direct influence of the bank on the target segment, but also the feedback from potential customers and clients on marketing measures taken.

An analysis of the current practice of marketing communications allows us to assert that the tools of marketing communications are used by banks in a complex, and not separately from each other, which gives grounds to use the concept of "marketing communications" and "integrated marketing communications" as synonyms in modern business realities. However, it is worth noting that the approach that integrates marketing communications has gained popularity among leading theorists and marketing practitioners since 1992, with the advent of D. Schulz and S. Tannenbaum. It is believed that this study became the conceptual basis for the further development of effective marketing decisions. Bank's marketing communications are a complex process, the main purpose of which is to promote the achievement of the bank's main goal of the activity. Proceeding from the above, the question arises of determining the essence of the category of "management of marketing communications". Thus, according to Romat E.V. marketing communications management is the process of interaction between the main actors in communication activities, where the management actors are the highest level of management, functional managers, and objects are potential clients, competitors, business partners .

Management of marketing communications is a complex of measures for the definition and practical implementation of marketing objectives of the subject of economic activity, implemented through the use of communication tools.

According to the chief marketing specialist Kotler F., under this concept it is necessary to understand the purposeful activity of the company in regulating market stability with the help of information technologies, promotion elements, advertising, PR, taking into account the influence of laws and market trends.

The use of the marketing communications system by banks makes it possible to have a targeted effect on certain segments of the audience, which allows more accurately identify the specific needs of potential customers and form tools for their more satisfactory satisfaction.

Famous scholars such as J. Burnet, C. Berry, J. Evans, F. Kotler, J. have devoted their research to the influence of marketing communications on the performance of various business entities. Lamben, S. Moriarty, A. Pulford, A. Smith, and others. The mathematical modeling of an advertising campaign, within the framework of the proposed approach of the scientists, is to optimize advertising costs with a forecast increase in revenue from the sale of goods or services and optimal distribution of the budget of an advertising campaign between types of advertising events - sources of mass media (Semiglazov, 2010).

The study of the effect of the application of a complex of marketing communications on the company's activities is devoted to a significant number of scientific works. Leading scholars, including Gatignon Yu, Hensens D., Seth S., Hartl R., Fittinger G., Montgomery D., Silk A., Yapal S., Edell J., Keller K., and many others were researched in their scientific The works of marketing interaction: the definition and proof of the existence of the effect of synergy from the use of a complex of marketing communications to various indicators of the firm.Famous scholars such as J. Burnet, C. Berry, J. Evans, F. Kotler, J. have devoted their research to the influence of marketing communications on the performance of various business entities. Lamben, S. Moriarty, A. Pulford, A.O. Romanov, A. Smith, etc. The mathematical modeling of an advertising campaign, within the framework of the proposed approach of the scientists, is to optimize the cost of advertising with the forecasted increase in revenue from the sale of goods or services and the optimal distribution of the budget of the advertising campaign between the types of advertising activities - sources of information (Semiglazov, 2010).

\section{Methods and results}

The methodological basis for cost optimization for tools of mass marketing communications is the complex analysis, systematization and further adaptation of existing scientific methodological approaches and mathematical models. The development of proposals for the formation and optimization of the budget of marketing communications of the bank used economic-mathematical modeling.

In the scientific field today, the issue of optimizing the costs of tools for mass marketing communications by carriers or tools is only gaining in popularity. The generalization of existing models and techniques that allow for optimization are presented in Figure 1. 
We characterize some of the models presented in Figure 1.

The mathematical model of a communication campaign has the form:

$c \sum_{j=1}^{m} k_{j} x_{j} \Rightarrow \max$

$\left\{\begin{array}{l}\sum_{j=1}^{m} a_{1 j} x_{j} \leq b_{1}, \\ \sum_{j=1}^{m} a_{i j} x_{j} \leq b_{i}, \\ \sum_{j=1}^{m} a_{n j} x_{j} \leq b_{n},\end{array}\right.$

$x_{j} \geq 0 ; i=\overline{1, n} ; j=\overline{1, m}$,

Notes: $a_{-i j}$ - share of costs per buyer of $j$-th group of $i$ - type of marketing communications, money. units / persons $b_{-} i$ - the total cost of each type of marketing communications in any communication campaign; $c$ - the cost of banking services; $x_{-j}$ - the number of persons in each target group who made the purchase of the goods or services; $k_{\lrcorner}$is the preferred price purchase factor for $\mathrm{j}$ target customer group.

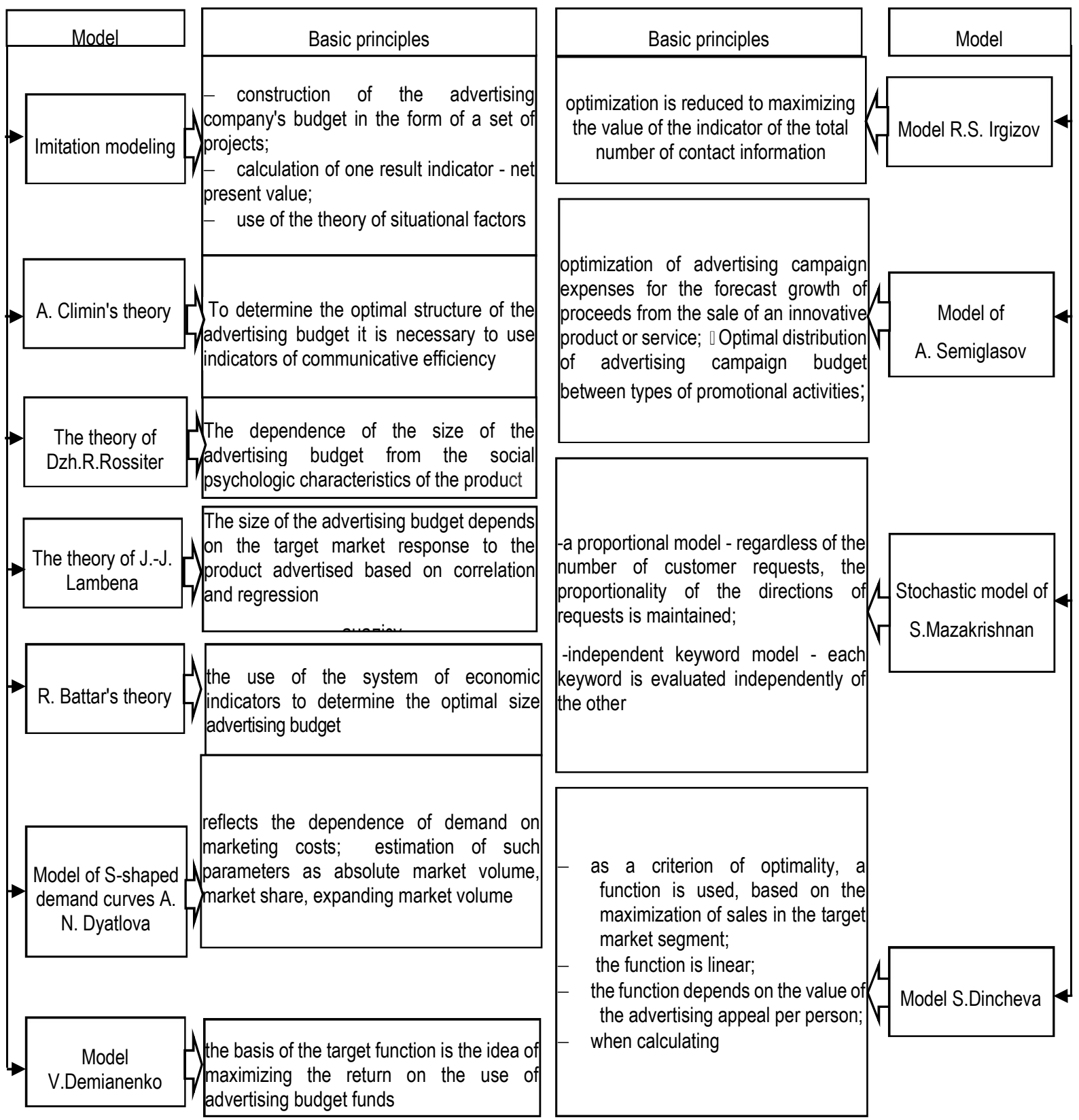

Figure 1. The main models of cost optimization for tools of mass marketing communications (compiled by authors on the basis of Semiglazov, 2010; Bove, 1995; Polyakova, 2009; Kim Ch, 2011; Markowitz, 1952. 
The system of equations is linear and allows (in the case of a well-known distribution of resources between types of advertising $b_{\mathrm{i}}$ ) the number of buyers of goods or service consumers in each target group $x_{\mathrm{j}}$.

In order to solve a more complex task - the optimal distribution of the total amount of funds $\mathrm{V}$ allocated to a communication campaign, taking into account the provision of the maximum number of savvy clients, the proposed systems of equations, on the proposal of the authors, need to be supplemented with the following restrictions:

$\sum_{1}^{n} b_{i} \leq V$

Further, using computer programs, in particular MS Excel, the tasks are solved. It is known that the market conditions are not static and most of the processes in the economy are changing rapidly. Scientists in their model suggest taking into account the number of customers, and, as you know, in today's conditions for the majority of business entities the possibility of deducting the exact number of customers is unlikely.

Thus, optimization of expenses for marketing communications at a forecasted increase in revenue from the sale of goods or services and the optimal distribution of the budget of the communication campaign between the types of marketing communications - the sources of mass information is fully based and depends on the exact number of customers, which is a major drawback of the methodology and significantly weaknesses it position, because the key feature of mass marketing communications is the wide reach of the audience. Taking into account to optimize the budget of the bank and, based on the number of buyers / consumers, to allocate financial resources between the tools of mass marketing communications is not feasible.

Methodology for analyzing the distribution of a marketing budget: advertising against the promotion of $\mathrm{C}$. Chim's marketing, which was not presented in Figure 1, due to limited tools, is based on the study of the level of spending on two tools of marketing communications - advertising and sales promotion. A fundamentally important characteristic of this technique is to take into account the focus on short- (sales promotion) or longterm (advertising) goals (Muthukrishnan, 2010). The methodology has been developed for the Japanese food market and, accordingly, tested on it. Based on the goals set out in this section of the dissertation research, as well as on the basis of the analysis of the scientific and methodical approach of $\mathrm{Ch}$. Kim, it should be noted that the application and adaptation of this technique is not appropriate for the modern domestic realities of the banking sector given the specifics of the Japanese market and the differences in a set of marketing communications tools. The stochastic model of budget optimization based on the search for advertising on the Internet is proposed by S. Mazakrishnan, M. Pol and Z. Svetlikina (Muthukrishnan, 2010). The essence of the approach is to deduct the number of clicks that match the keywords of random variables during the search. The authors distinguish three possible variants of the model: proportional (the number of users, clicks and their requests varies daily, and the proportions of clicks on different keywords remain unchanged); independent keyword model (each keyword is programmed with its own click probability and the dependency / independence of the number of clicks is calculated in different directions); script method (several scenarios are proposed, each of which specifies the exact number of clicks for each keyword) (Polyakova, 2009; Muthukrishnan, 2010). In our opinion, the feasibility of using this scientific methodology is justified only when the bank carries out a large-scale advertising campaign on the Internet, as well as - as an auxiliary method for a more complete and accurate analysis of the distribution of financial resources on the Internet as a channel for distributing information about the bank. Given the popularity of banking services on the Internet, this technique can be very relevant and useful in use.

Consequently, most of the existing methods and models are static and aimed at changes in the external environment, which is one of the most difficult conditions for the formation of economic relations. In our opinion, the mandatory condition for the formation of an effective budget is to take into account the feedback of the external environment on the promotion of a product or service (Bove, 1995).

Therefore, based on the above, one can conclude that the problem of optimizing the budget of advertising has not been solved, therefore a scientific methodical approach is proposed to determine the optimal distribution of financial resources between the tools (carriers) of the advertising campaign in order to effectively form the budget of marketing communications of the bank.

Of particular relevance in this aspect is the definition of adequate media combination - the combination of media elements, namely the combination of type (television, radio, periodicals), the type (specific television channel, print edition or radio station), the place (time) of placement, the number of repetitions of advertising (Semiglasov, 2010). 
Taking into account all the disadvantages of the considered methods of optimizing the budget, the model of portfolio optimization G. Markovitsa (Semenchin, 2010) will be based on the author's scientific-methodical approach. The essence of this model is to determine the optimal correlation between the level of profitability, which is determined at the limit of the maximum and the level of risk, which is determined at the limit of the minimum. The objective prerequisite for choosing this model is: recognition of costs for the tools of mass marketing communications as an investment, and the basis of the model in the author's interpretation is to determine the optimal relationship between the elasticity of the change in the scope of the provision of banking services in relation to the change in the cost of using mass marketing communications tools and the risk, calculated as the volatility of this elasticity; when using marketing communications it is necessary to take into account the time gap (lag) that arises when investing financial resources in marketing communications and obtaining an effect from them; investments in marketing communications are accompanied by various risks: rejection of the market environment of marketing communications, oversaturation of the market by banking services, incorrect selection of structural elements of the management system of marketing communications, etc.

One of the challenges faced by the bank when optimizing the cost of tools for mass marketing communications is to determine and consider the time lag from investing in marketing communications, which is reflected in fluctuations in the volume of the client base. This time gap was calculated for the branch - the Sumy Regional Department of JSC "Oschadbank", the results of which are presented in Table. 1. Taking into account a number of limitations and assumptions in the model G. Markovitsa, in order to achieve the goal of optimizing the budget of advertising, the following assumptions are assumed:

as the elasticity of the tools of mass marketing communications, the mathematical expectation of elasticity is considered, which considers the entire client base, regardless of the type of banking services purchased by the client; as a risk of tools for mass marketing communications - the mean square deviation of elasticity;

data from previous periods used in elasticity and risk calculations fully characterize its future values;

the degree and nature of the relationship between the tools of mass marketing communications is calculated using a linear correlation coefficient (covariance).

Table 1. Functional dependence between separate items of expenses on marketing communications and growth rates of the client base of the bank for the branch - Sumy Region Department of Oschadbank JSC in 2012-2016

\begin{tabular}{|c|c|c|c|}
\hline \multirow[t]{2}{*}{ № } & \multirow[t]{2}{*}{ Expenditures on marketing communications } & \multicolumn{2}{|c|}{$\begin{array}{c}\text { The time lag of the reaction of changing the client base to } \\
\text { separate items of the bank's expenses on marketing } \\
\text { communications }\end{array}$} \\
\hline & & Time Lag is absent & Lag 1 month \\
\hline 1. & Costs for advertising in mass media and other media & 0.46968 & 0.1727 \\
\hline 2. & $\begin{array}{l}\text { Costs for the development of advertising materials and } \\
\text { the production of audio-video advertising }\end{array}$ & 0.49275 & -0.1486 \\
\hline 3. & Costs for the production of advertising printing products & 0.44492 & 0.0324 \\
\hline 4. & The cost of production of outdoor advertising & 0.00151 & 0.0949 \\
\hline 5. & $\begin{array}{l}\text { The cost of promotional activities that are aimed at } \\
\text { supporting the image and reputation of the bank }\end{array}$ & 0.00151 & 0.5262 \\
\hline
\end{tabular}

According to Markovitz's approach proposed by Markovitz (1952), the expected elasticity of the tools of mass marketing communications is taken as the average value of the time of the previous values of its elasticity, and the risk as the mean-square deviation, which enables, at a certain value of elasticity, to minimize the risk, minimizing the mean-square deviation of the population tools of mass marketing communications. This model makes it possible to take fully into account the investment activity, which is a positive moment in view of the recognition in the dissertation study of the cost of marketing communications investments.

Having determined the subject area of the task of optimizing the costs of tools for mass marketing communications, the identification of the goal, which is to choose among the whole set of tools of mass marketing communications is precisely such a media combination, which would enable not only to optimize the structure of the budget, but also to protect the bank from biased leakage financial resources, ensuring its stability. 
The mathematical formalization of G. Markowitz's model in the context of this dissertation study will look like:

$\left\{\begin{array}{c}\sum_{i=1}^{n} \sigma_{i}^{2} x_{i}^{2} \rightarrow \min \\ \sum_{i=1}^{n} R_{i} x_{i}=\varphi, \\ \sum_{i=1}^{n} x_{i}=1, \\ x_{i} \geq 0, i=1, \ldots n\end{array}\right.$

where $x_{i}$-share of the budget of expenses for mass marketing communications of the bank, directed to the use of their tools; $R_{i}-$ the mathematical expectation of the elasticity of changes in the volume of provision of banking services in relation to the change in the cost of the use of the instrument of mass marketing communications of the bank; $\sigma_{i}^{2}$ - the standard deviation of the elasticity of changes in the volume of provision of banking services in relation to the change in the cost of the use of the instrument of mass marketing communications of the bank; $\varphi$ - expected by the bank the level of change in the volume of services rendered as a result of the application of the entire set of instruments of mass marketing communications of the bank. Maximizing the expected level of elasticity of a particular advertising tool at a given level of risk determines the need for two-criterion optimization, which can be reflected:

$\left\{\begin{array}{c}\sum_{i=1}^{n} R_{i} x_{i} \rightarrow \max \\ \sum_{i=1}^{n} \sigma_{i}^{2} x_{i}^{2}=\psi, \\ \sum_{i=1}^{n} x_{i}=1, \\ x_{i} \geq 0, i=1, \ldots n\end{array}\right.$

where $\psi$-permissible risk level for the bank.

Thus, we will directly implement the formalization of the proposed scientific methodological approach to optimizing the costs of tools for mass marketing communications.

The elasticity of the tools of mass marketing communications is defined as the coefficient of change in the total sales when the cost of instruments is changed by one percent. In the scientific literature, this dependence is established: demand is directly proportional to the positive influence of the tools of mass marketing communications and inversely proportional to the negative. In this case, the resultant indicator will be a change in the volume of sales, and the change in the number of customers who have taken advantage of banking services (how much the percentage of customers will change from the $1 \%$ change in the cost of tools for mass marketing communications).

According to G. Markovitz, the value of elasticity can be regarded as random variables distributed by the Gauss law (the law of normal distribution) (Markowitz, 2010). Based on this, the bank's management, when executing the budget optimization task, will evaluate only two indicators: $R$ is the expected elasticity and $R$ is the standard deviation as a measure of risk. Consequently, it is necessary to evaluate the elasticity and standard deviation of each tool of mass marketing communications in order to select the most optimal combination of tools that will meet the goal of ensuring the maximum increase in the number of clients $R$ provided that an acceptable level of risk and volume of expenditure $\sigma$. Taking into account the indication, we will calculate the elasticity of the tools of mass marketing communications on the example of the branch - the Sumy Regional Department of JSC "Oschadbank" (Table 2), in order to obtain more concrete results, it is expedient to calculate both the overall level of elasticity (for aggregate costs) and for separate items of marketing communications expenses.

Table 2. Calculation of the average levels of elasticity of the instruments of mass marketing communications for the branch - Sumy regional administration of JSC "Oschadbank", for the period of 2012-2016,\%

\begin{tabular}{|c|c|c|c|c|c|c|}
\hline \multirow[b]{2}{*}{ Years } & \multicolumn{6}{|c|}{ Cost item } \\
\hline & $\begin{array}{l}\text { Costs for } \\
\text { advertising } \\
\text { in mass } \\
\text { media and } \\
\text { other media }\end{array}$ & $\begin{array}{l}\text { Costs for the } \\
\text { development of } \\
\text { advertising } \\
\text { materials and the } \\
\text { production of audio- } \\
\text { video advertising }\end{array}$ & $\begin{array}{l}\text { Costs for the } \\
\text { production of } \\
\text { advertising } \\
\text { printing } \\
\text { products }\end{array}$ & $\begin{array}{l}\text { The cost of } \\
\text { production of } \\
\text { outdoor } \\
\text { advertising }\end{array}$ & $\begin{array}{l}\text { The cost of } \\
\text { promotional } \\
\text { activities } \\
\text { aimed at } \\
\text { maintaining } \\
\text { the image and } \\
\text { reputation of } \\
\text { the Bank }\end{array}$ & $\begin{array}{c}\text { Total } \\
\text { expenses of } \\
\text { the bank on } \\
\text { marketing } \\
\text { communicatio } \\
\text { ns }\end{array}$ \\
\hline 2012 & 0.00 & -0.02 & 0.26 & 0.01 & 0.00 & 0.18 \\
\hline 2013 & -4.09 & -0.07 & -0.36 & -0.10 & -0.01 & -0.27 \\
\hline
\end{tabular}


Table 2 (cont.). Calculation of the average levels of elasticity of the instruments of mass marketing communications for the branch - Sumy regional administration of JSC "Oschadbank", for the period of 2012$2016, \%$

\begin{tabular}{|l|c|c|c|c|c|c|}
\hline 2014 & 0.91 & 0.00 & -0.01 & 0.00 & 0.00 & -0.07 \\
\hline 2015 & -0.06 & 0.00 & -0.23 & 0.00 & 0.00 & -0.35 \\
\hline 2016 & -0.13 & 0.02 & -0.30 & 0.00 & 0.00 & -1.52 \\
\hline for the entire study period & -0.68 & -0.02 & -0.13 & -0.02 & 0.00 & -0.40 \\
\hline
\end{tabular}

As can be seen from Table 2, the percentage change in the number of clients of the bank is less than the change in the cost of marketing communications (both in separate items of expenditure, and in general, the bank).

With increasing costs for marketing communications, the total number of clients of the bank increases, and with a decrease - there is a reduction. The obtained results testify to the presence of positive / negative reaction of the volume of clients on the corresponding changes in the volumes of expenses for tools of mass marketing communications. Thus, we will calculate the effect of changes in costs on the volume of the client base of the bank. Thus, on the basis of the obtained results we make mathematical calculations of the necessary indicators of the modified model G. Markovitz, presented in Table 3.

Table 3. Forecasted value of the influence of interest rate changes on the number of affiliate clients - Sumy Oblast Department of JSC 'Oschadbank' in 2012-2016, persons.

\begin{tabular}{|c|l|c|c|c|c|}
\hline \multirow{2}{*}{ № } & \multirow{2}{*}{ Article Marketing Costs } & \multicolumn{3}{|c|}{ The meaning of changing indicators } \\
\cline { 3 - 6 } & & \multicolumn{2}{|c|}{$\begin{array}{c}\text { increase in reduction } \\
\text { costs }\end{array}$} & \multicolumn{2}{|c|}{ increase in reduction costs } \\
\cline { 3 - 6 } & & $10 \%$ & $20 \%$ & $10 \%$ & $20 \%$ \\
\hline 1. & Total advertising costs & 19249 & 125922 & -194095 & -300768 \\
\hline 2. & Costs for advertising in mass media and other media & 93920 & 275263 & -268766 & -450109 \\
\hline 3. & $\begin{array}{l}\text { Costs for the development of advertising materials and the production of audio- } \\
\text { video advertising }\end{array}$ & 92757 & 98090 & -76756 & -82089 \\
\hline 4. & Costs to produce advertising printing products & 122092 & 156760 & -18086 & -52754 \\
\hline 5. & Expenditure on the production of outdoor advertising & 92757 & 98090 & -76756 & -82089 \\
\hline 6. & $\begin{array}{l}\text { Expenditure on promotional activities aimed at supporting the image and } \\
\text { reputation of the bank }\end{array}$ & 87423 & 87423 & -87423 & -87423 \\
\hline
\end{tabular}

It should be noted that under these conditions, the definition of the numerical equivalent of percentage values for each of the articles of expenditure on the tools of mass marketing communications is a necessary element of this dissertation study. Having analyzed the activity of the branch - the Sumy Regional Directorate of JSC "Oschadbank" on the basis of statistical data of the bank's work during 2012-2016, it was discovered that the optimal proportions of the distribution of the budget of the bank's expenses on advertising as an instrument of mass marketing communications are:

expenses for advertising in mass media and other media $-54,12 \%$;

expenses for development of advertising materials design and production of audio-video advertising - 8.71\%; expenses for the production of advertising printed materials $-4.74 \%$;

expenses for the production of outdoor advertising $-13.89 \%$;

expenses on promotional measures aimed at supporting the image and reputation of the bank $-18.54 \%$

Table 4. Calculation of the main components for determining the level of risk for various items of expenses for the tools of mass marketing communications for a branch - Sumy Oblast Department of JSC

"Oschadbank" based on statistical data of the bank's operation during 2012-2016,\%

\begin{tabular}{|c|c|c|c|c|c|c|c|c|c|c|c|c|c|c|c|c|}
\hline \multirow[b]{2}{*}{ № } & \multirow{2}{*}{$\begin{array}{l}\text { Article } \\
\text { Marketing } \\
\text { Marketing } \\
\text { Costs }\end{array}$} & \multicolumn{5}{|c|}{ Mathematical expectation } & \multicolumn{5}{|c|}{ Averaged deflection } & \multicolumn{5}{|c|}{ Coefficient of variation } \\
\hline & & $\stackrel{\sim}{\stackrel{\sim}{*}}$ & $\stackrel{m}{\stackrel{n}{\sim}}$ & $\underset{\sim}{\stackrel{\Delta}{d}}$ & $\frac{n}{\stackrel{n}{d}}$ & $\stackrel{0}{\stackrel{i}{d}}$ & $\stackrel{\sim}{\stackrel{\sim}{*}}$ & $\stackrel{m}{\stackrel{n}{\sigma}}$ & $\underset{\sim}{\stackrel{\Delta}{d}}$ & $\frac{n}{\stackrel{n}{c}}$ & $\stackrel{\circ}{\stackrel{\sim}{*}}$ & $\stackrel{\sim}{\stackrel{\sim}{\sim}}$ & $\stackrel{m}{\stackrel{n}{\sigma}}$ & $\underset{\sim}{\stackrel{\Delta}{d}}$ & $\stackrel{n}{\stackrel{n}{c}}$ & $\stackrel{\circ}{\stackrel{\sim}{\sim}}$ \\
\hline 1. & $\begin{array}{l}\text { Total } \\
\text { advertising } \\
\text { costs. Incl .: }\end{array}$ & 0.185 & 0.268 & 0.068 & 0.349 & 1.523 & 0.281 & 0.574 & 0.804 & 1.062 & 3.972 & 15.8 & 21.4 & 118.2 & 30.4 & 26.1 \\
\hline
\end{tabular}


Table 4. Calculation of the main components for determining the level of risk for various items of expenses for the tools of mass marketing communications for a branch - Sumy Oblast Department of JSC

"Oschadbank" based on statistical data of the bank's operation during 2012-2016,\%

\begin{tabular}{|c|c|c|c|c|c|c|c|c|c|c|c|c|c|c|c|c|}
\hline 2. & \begin{tabular}{|lr} 
Costs & for \\
advertising in \\
mass & media \\
and & other \\
media & \\
\end{tabular} & 0.005 & 4.090 & 0.906 & 0.065 & 0.134 & 0.031 & 14.743 & 3.190 & 0.524 & 0.328 & 62.0 & 36.1 & 35.2 & 80.6 & 24.5 \\
\hline 3. & $\begin{array}{l}\text { Expenses for } \\
\text { development } \\
\text { of advertising } \\
\text { materials } \\
\text { design and } \\
\text { production of } \\
\text { audio-video } \\
\text { advertising }\end{array}$ & 0.023 & 0.071 & 0.002 & 0.000 & 0.015 & 0.256 & 0.241 & 0.027 & 0.000 & 0.049 & 111.3 & 33.9 & 135.0 & - & 32.6 \\
\hline 4. & $\begin{array}{l}\text { Expenses for } \\
\text { the production } \\
\text { of advertising } \\
\text { printing } \\
\text { products } \\
\end{array}$ & 0.257 & 0.361 & 0.014 & 0.229 & 0.304 & 0.617 & 0.988 & 0.230 & 0.607 & 0.622 & 24.0 & 27.3 & 164.3 & 26.5 & 20.4 \\
\hline 5. & \begin{tabular}{|ll} 
Expenses to \\
produce \\
outdoor \\
advertising \\
\end{tabular} & 0.011 & 0.100 & 0.000 & 0.001 & 0.003 & 0.025 & 0.211 & 0.000 & 0.024 & 0.009 & 22.7 & 21.1 & - & 240.0 & 30.0 \\
\hline 6. & $\begin{array}{l}\text { The costs of } \\
\text { promotional } \\
\text { activities that } \\
\text { support the } \\
\text { image and } \\
\text { reputation of } \\
\text { the bank }\end{array}$ & 0.005 & 0.012 & 0.001 & 0.003 & 0.002 & 0.031 & 0.251 & 0.022 & 0.029 & 0.030 & 62.0 & 209.2 & 220.0 & 96.7 & 150.0 \\
\hline
\end{tabular}

\section{Conclusions}

On the basis of the received calculations, it is possible to formulate recommendations regarding the vector orientation of the distribution of costs for the tools of mass marketing communications in order to optimize them, which for the branch - Sumy Oblast Administration of JSC "Oschadbank" will be in the following: First, the total amount spent in support of the whole image and reputation of the branch - Sumy region administration of JSC "Oschadbank" during 2012-2016 did not bring visible results, which resulted in the presence of limits in increasing the number of clients (approximately about 90 thousand acres) with any change in the amount of expenses for maintaining the image. Thus, from the point of view of the formation of an optimal budget for marketing communications, this article of expenditure should be somewhat reduced. Secondly, the calculations made allow us to justify the size of the share of expenses for the development of advertising materials and the cost of manufacturing outdoor advertising in the budget of marketing communications. The results of the calculations shown in Table. 3 , is an objective basis for the assignment of equal values of weight coefficients in the structure of total costs for marketing communications. Thirdly, the largest share of costs should be allocated to the costs associated with both the production of advertising printed materials and the placement of advertising in the media and other media.

The obtained results allow to use the given recommendations reasonably, since with the increase of these items of expenses by $1 \%$, the largest increase in the number of clients is observed. Therefore, based on the calculated levels of elasticity of the instruments of mass marketing communications of the bank, it is necessary to allocate financial resources between the proposed article in the author's correspondence, which will provide an opportunity to increase the level of budget efficiency on marketing communications, and reduce the level of risks associated with components of the market relations of the bank.

Advantages of using the adapt model G. Markovitz's banks are as follows:

1) taking into account the volatility of the reaction of consumers to the use of various tools of marketing communications of the bank (by including in the model of the indicator $\sigma_{i}^{2}$ );

2) taking into account the prevailing trends in the market perception of consumers of various tools of marketing communications of the bank (by including in the model of indicator $R_{\mathrm{i}}$ ); 
3) taking into account the risk of not receiving the expected effect of the bank from the use of marketing communications tools of the bank.

\section{References}

1. Desenvolver o Mercado de Comunicação Digital Interativa no Brasil. Missão do IAB Brasil. Available at: http://www.iabbrasil.org.br/arquivos/doc/Indicadores/Indicadores-de-Mercado-IAB-Brasil.pdf.

2. Hanssens D. (1987). Modeling Marketing Interactions with Application to Salesforce Effectiveness, Journal of Marketing Research, 247-257.

3. Doran G. T. (1981). There's a S.M.A.R.T. way to write management's goals and objectives. Management Review, 70(11), 35-36.

4. Edell J. A., Keller K. L. (1989). The information processing of coordinated media campaigns, Journal of Marketing Research, 26, 149-163.

5. Edell J. E., Keller K. L. (1999). Analyzing Media Interactions: The Effects of Coordinated TV-Print Advertising Campaigns, Cambridge, MA : Marketing Science Institute, Working Paper №99, 90-120 .

6. Ennew C., Wright M, Kirnag, J. (1996). The development of bank marketing in Eastern Europe: The case of Slovakia, Service Industries Journal, 443-457.

7. Feichtinger G., Hartl R., Sethi S. (1994). Dynamic Optimal Control Models in Advertising: Recent Developments, Management Science, 40(2), 195-226.

8. Gopalakrishna S., Chatterjee R. A. (1992). Communications Response Model for a Mature Industrial Product: Application and Implications, Journal of Marketing Research, 29, 189-200.

9. Herbig P. Marketing japanese style. Available at: http://www.questia.com/PM.qst?a $=0 \& d=23374057$.

10. Jagpal Sh. (1999). Marketing Strategy and Uncertainty, York: Oxford University Press, 300-352.

11. JOM Jäschke Operational Media. Available at: http://www.jomhh.de/.

12. Kaijansinkko R. Product Placement in Integrated Marketing Comminications Strategy. Available at: http://www.doria.fi/bitstream/handle/10024/35143/nbnfi-fe20031411.pdf?sequence=1.

13. Kalyan R., Prasad A. Integrated Marketing Communicatoins in Retailing. Available at: http://ramanassoc. com/yahoo site admin/assets/docs/IMC in Retailing.26100503.pdf.

14. Kim Ch. (2011). An Exploratory Analysis of Marketing Budget Allocation: Advertising vs. Sales Promotion, The Ritsumeikan Business Review, 2-3, 91-111.

15. Laitinen J.-M. Marketing Communication Plan. Case DNA Finland Ltd: How to Gain More Russian Prepaid Subscription Customers? Available at: http://publications.theseus.fi/bitstream/handle/10024 /2618/Laitinen Jenni-Mari.pdf.

16. Semiglazov, A. M.. Semiglazov, V. A.. Ivanov, K. I. (2010). Matematicheskoye modelirovaniye reklamnoy kampanii Upravleniye. vychislitelnaya tekhnika i informatika. Doklady Tomskogo gosudarstvennogo universiteta sistem upravleniya i radioelektroniki [Mathematical modeling of advertising campaigns. computer science and computer science. Reports of Tomsk State University of Control Systems and Radioelectronics], 2 (22), 342-349.

17. Polyakova, Ya. A. (2009). Opredeleniye struktury reklamnogo byudzheta na osnove imitatsionnogo modelirovaniya [Determination of the structure of the advertising budget on the basis of simulation modeling], Business Inform, 1, 129-133.

18. Markowitz H. (1952). Portfolio Selection, Journal of Finance, 77-91.

19. Muthukrishnan, S., Pal M., Svitkina, Z. (2010). Stochastic Models for Budget Optimization in SearchBased Advertising, Algoritmica, 58, 1022-1044. 